\title{
Flow, Liminality, and Eudaimonia: Pagan Ritual Practice as a Gateway to a Life With Meaning
}

\section{Charmaine Sonnex', Chris A. Roe ${ }^{2}$ iD, and Elizabeth C. Roxburgh ${ }^{3}$ iD}

\begin{abstract}
Paganism is a term applied to a number of nature religions based on traditional indigenous practices. Paganism is practiced through rituals designed to facilitate a flow state that allows practitioners to use magic to achieve their aims. Since the introduction of Wicca to mainstream society in the 1950s, many other Pagan traditions have developed. Similarly, the number of people identifying as Pagan has also increased; in $201 \mathrm{I}$, the number of people identifying as Pagan in the U.K. census reached 80,153. Despite this growth, Paganism is a topic that is underresearched in Psychology. This article uses Ryff's theory of psychological well-being as a frame-work through which to explore the ways in which Paganism may be particularly conducive to eudemonic well-being as a result of the flow experiences inherent in its practice. This theory posits six key dimensions of eudaimonia: personal growth, self-acceptance, positive relation with others, autonomy, environmental mastery, and purpose in life. The ways in which each of these dimensions is elicited through Paganism is elucidated.
\end{abstract}

\footnotetext{
'University of Buckingham, Buckingham, UK

${ }^{2}$ University of Northampton, Northampton, UK

${ }^{3}$ Canterbury Christ Church University, Canterbury, UK
}

\section{Corresponding Author:}

Charmaine Sonnex, University of Buckingham, Buckingham, MKI8 IEG, UK.

Email: charmaine.sonnex@buckingham.ac.uk 


\section{Keywords}

meaning in life, paranormal, personal growth, psychology of religion, religion, self-acceptance, spirituality, transpersonal psychology, well-being

\section{Introduction}

Paganism is used as an umbrella term for a number of different nature-based religions/spiritualities that are inspired by the native pre-Christian traditions of (mainly) Europe (Clifton \& Harvey, 2004; Jones, 1998; York, 1995). Paganism is a burgeoning belief system; the UK census shows that the number of people who labelled their religion as "Pagan" almost doubled from 42,262 in 2001 to 80,153 in 2011 (Office for National Statistics, 2001, 2012). Pagan understandings of divinity vary, but tend to be animistic, pantheistic, and polytheistic "in recognising a plurality of divine beings which may or may not be reducible to an underlying One, or Two, or Three, etc." (Jones, 1996, p. 34). This plurality of divinity is most commonly seen as a complementarity of Goddess and God. Animism and pantheism are exemplified by the range of other entities that feature as part of Pagan practices, such as the spirits of the elements (Earth, Air, Fire, Water). In this article, we will describe how Paganism involves forms of magical practice that are intended to enable the adherent to interact with these entities and the mystical world that they inhabit. This is enacted through ritual workings ${ }^{1}$ either individually (known as solitary practice) or as part of a group (sometimes referred to as a coven). Pagan rituals can serve a number of purposes, they are "performed to celebrate the seasons, honour the deities, attune with nature, attain self-realisation, induct participants into the mysteries, and for magical and healing purposes" (Hume, 1998). The design and performance of Pagan ritual is a creative enterprise where practitioners express their aims through symbolism (Butler, 2004; Hume, 1998; Rountree, 2006).

The structure of Pagan practice is similar to Van Gennep's tripartite model of ritual (Butler, 2004; Magliocco, 1996), consisting of the stages shown in Figure 1:

The separation from daily life is most clearly embodied in the casting of a magic circle - the sacred space that Pagans create in which to conduct their rituals. Unlike many other religions, Paganism has no dedicated places of worship that adherents attend; instead, they create their sacred spaces each time they wish to practice in a process called "casting the circle." This entails demarcating the boundary of the circle (using physical markers such as salt, rocks, or candles) and through the use of magical tools such as a magic wand or athame (ritual knife) to manipulate subtle energies, and then consecrating the space by invoking entities such as the elemental spirits and 


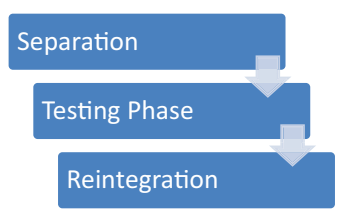

Figure I. The tripartite model of ritual.

deities of choice, inviting them into the circle to bless it by their presence and lend their energy to the workings within it (Magliocco, 1996). It is here that the first elements of liminality in Paganism become evident. The term liminal comes from the Latin "limen" meaning threshold (Reber, 1985, p. 404). A liminal space therefore is one that exists at the interface of two others; this threshold can be literal (e.g., a border between countries) or figurative (e.g., the hypnagogic state of consciousness, between wakefulness and sleep). Circles are most often created in the practitioner's house so as to establish a boundary between the everyday, profane world that surrounds them and a space within which they can interact with the sacred. The practitioner works with otherworldly entities and magic in a space that has been sanctified and separated from the mundane world yet is located very visibly within it. The notion that the circle separates one from the real world is common within Pagan introductory texts, and the magic circle is often described as existing "between the worlds" (Adler, 1986, p. 109; Green, 1991, p. 59; Orion, 1995, p. 32; Starhawk, 1989, p. 72). The concept of liminality is clearly an important aspect of the separation element of ritual.

The testing phase in Neo-Pagan workings refers to the ritual that occurs within the sacred circle. It is referred to as a "testing" because, as Magliocco (1996, p. 102) explains, this process "requires each participant's undivided attention and tests the strength of the circle." As each Pagan ritual differs according to its purpose, it is difficult here to outline exactly what ritual entails, though in general terms it involves "raising" (i.e., creating) energy, imbuing it with a purpose and directing that energy towards a suitable target (Adler, 1986; Cunningham, 2003; Magliocco, 2004; Sonnex, 2017). Rituals to celebrate the Sabbats (holy days of astronomical or agricultural importance such as solstices, equinoxes, harvests) often reflect the period of the year in which they are being celebrated; for instance, Beltane (April 30 in the Northern Hemisphere and October 31 in the Southern Hemisphere) marks the start of summer, when nature is coming into full bloom, and so rituals to mark this day often involve dramatic representations of fertility and fecundity such as maypole dances and weaving (Magliocco, 2004), and energy raised during 
these rites will be directed toward growth and abundance. Bespoke spells may be less elaborate but still use metaphor; for example, simple candle magic often involves inscribing an appropriately colored candle (such as pink for love) with a symbol representing the desired aim (such as a love heart) and burning it while visualizing the desired outcome. The energy raised and programmed through this visualization is considered to be "sent" when the candle is extinguished.

Some scholars consider Pagan ritual to be a form of folk art, likened particularly to theatre by virtue of the performative nature of ritual, the use of props (i.e., paraphernalia such as wands, candles, incense, and costume in the form of ritual dress), and staging in the form of the creation of the magic circle (cf., Hume, 1998; Magliocco, 1996). Butler (2004, p. 110) explains that "the 'audience' for neo-pagan performance included the earthly participants of the ritual itself, and also, perhaps, the unseen entities believed to be present during the performance." Like traditional theatre, the use of costume, sets, and props is designed to create a liminal atmosphere, to distinguish events from everyday reality, to spark the imagination of participants, and to fully immerse them in the world created "on the stage."

However, unlike theatre, Pagan ritual performance is deeply infused with symbolism and meaning (Butler, 2004; Hume, 1998; Magliocco, 1996; Rountree, 2006). Pagans use real objects as symbolic representations of the spell in multiple ways. First, they act as mnemonic devices, providing a tangible connection to the intentions, such as a toy eyeball being used to represent a real eye in healing spells focused on this organ (Sonnex, 2017). Second, some objects are believed to have magical correspondences or energetic kinships that help to boost the energy created by the practitioner, thus, aiding in the spell work. Symbols can also contribute to the liminal atmosphere of a working, especially when they engage the senses; for example, by incorporating music, chanting, or incense. A number of authors have argued that such symbolic representations serve both esoteric and practical purposes in spell work (Adler, 1986; Luhrmann, 1989; Magliocco, 2004). Pagan author Starhawk (1989) explains that the symbolic aspects of ritual are intended to facilitate communication with the unconscious, "arousing the emotions as well as the intellect" (p. 124). Similarly, noted Pagan practitioners Janet and Stewart Farrar (1992) explain the use of ritual and representations as a means of engaging with multiple levels of reality that each understand different "languages" ranging from words and logic in the lower levels to symbols, images, and emotions in the higher levels. By using symbols in this way, spellcasting becomes a more immersive, liminal experience that engrosses every aspect of the mind. 
The final stage of the tripartite model of ritual involves the reintegration into society, and occurs when the ritual comes to an end. At this point practitioners will "ground" the energy that they have raised during ritual and then close (i.e., dismantle) the sacred circle. Grounding of energy tends to occur in two ways. One is through visualization, usually imagining roots growing from one's feet into the earth, allowing the excess energy to flow through the roots and out of the body (much like earthing electricity). The other is through the consumption of blessed food and drink (usually referred to as "cakes and wine") which is believed to help in returning to an ordinary state of consciousness by bringing awareness back to the body, and to the mundane world. The process for dismantling the circle is the reverse of the process for casting it, the entities that were invoked are thanked for their presence and bade farewell, the energetic boundaries are dissolved through visualization, and the physical circle is packed away. These acts indicate the end of the ritual and a return to the mundane world (Butler, 2004; Magliocco, 1996).

Liminality is believed to be necessary for workings because the manipulation of energy that comprises magic is not possible in an ordinary state of consciousness, and creating a feeling of liminality facilitates the shift in consciousness required. Adler (1986), Orion (1995), and Starhawk (1989) all conceive of this altered state of consciousness (ASC) as a change in perception, from profane to sacred, from narrow and limited to holistic and expansive. Researchers exploring the phenomenology of ritual practices (e.g., Ezzy, 2014; Shadrack et al., 2019; Sonnex, 2017) equate this ASC with Csikzentmihalyi's Flow experience, which is described as "the holistic experience that people feel when they act with total involvement" (Csikszentmihalyi, 1975, p. 36) and is considered a liminal experience (Turner, 1983). The phenomenology of ritual that Pagan practitioners report shares many characteristics with the phenomenology of flow. Sonnex (2017, pp. 169-170) reports that this was a defining feature of ritual phenomenology discussed by interviewees, with one participant stating "[people] use ritual because it makes it easier to [ . . ] focus on the intent." Practitioners also discussed the merging of action and awareness that characterizes the flow state; as another participant explained "the [spells] that do work seem effortless" (p. 169). Luhrmann (1989) provides an account of Pagan ritual phenomenology that very clearly demonstrates the parallels between the two states:

One officer [... ] said she is "not there" when the ritual is good: she becomes a "channel" for the forces. For William [ . . . ] the difference between powerful and powerless ritual was whether he was "doing" or "being done." 
When he was "doing," the ritual hadn't taken over. It was "empty." When the rite was good, it felt as if something was acting through him and that he himself was absent. In such rituals his normal sense of space and time alters, and he knows that the only things of consequence lie within the confines of the rite. A witchcraft priest told me that "when it [the ritual] works, then my personality—me, Paul—steps aside, and someone else takes over." (p. 134)

Lurhmann's participants describe experiences that are indicative of flow; awareness and action merge as people feel "taken over" by the ritual, focus is limited to the events in the circle, there is a distortion in their temporal and spatial awareness, and they experience a loss of reflective self-consciousness. Bloch (2000) explains that discussions of flow in academic literature tend to take one of two approaches: seeing flow as boundary transcending; or seeing flow as quality of life. The liminal nature of Pagan ritual suggests that practitioners' flow experiences would fit into understandings of it as boundary transcending. In this article, we will argue that the liminal, transcendent, flow experiences within Pagan ritual also fit into understandings of flow as quality of life, promoting feelings of well-being.

\section{Eudaimonia}

Ezzy (2014, p. 16) proposes that these liminal, ritual flow experiences allow one to discover a life with "soul"; that is, "a life that is experienced as worthwhile, and performed with dignity and respect." This definition shares many similarities to Eudaimonia, a term that comes from Aristotle's Nichomachean Ethics and refers to living in accordance with one's daimon - one's full potential or true self (Ryff \& Singer, 2008; Waterman, 1993). The eudemonic approach therefore views well-being as being akin to self-actualization and fulfilling one's potential, in contrast to the hedonic approach, which considers well-being to be the presence of positive affect and the absence of negative affect (Ryan et al., 2008). Thus, whereas hedonic well-being is concerned with the outcomes of actions, eudemonic well-being is concerned with the processes; that is, the question becomes "are we living well?" rather than "are we feeling good?" (Ryan \& Deci, 2001). It is clear that this approach to well-being has much in common with Humanistic theories of optimal functioning.

There are three key theories of Eudaimonia: Waterman's (1990, 1993) theory of personal expressiveness, Deci and Ryan's (2008b) self-determination theory, and Ryff's (1989) theory of psychological well-being (PWB). This article will focus on eudaimonia as PWB because it has a strong theoretical grounding, and accommodates a diverse range of existing theories 
from areas such as life-span development, humanistic psychology, existential psychology, clinical psychology, and utilitarian philosophy (Ryff \& Singer, 2008). The result is a comprehensive theory that posits Eudaimonia as being composed of six core dimensions:

- Personal growth

- Self-acceptance

- Positive relation with others

- Autonomy

- Environmental mastery

- Purpose in life

The link between religiosity/spirituality and eudaimonia has been suggested previously (e.g., Dierendonck \& Mohan, 2006; Pargament et al., 2016). However, this research has not considered Pagan practices. In the remainder of this article, we will consider the ways in which Pagan practice might engender eudaimonia by reflecting on the six dimensions proposed by Ryff (1989).

\section{Personal Growth}

The first PWB dimension to consider is Personal growth, since this is the dimension that most closely resembles eudaimonia as described by Aristotle (cf. Ryff \& Singer, 2008), and is inspired by humanistic theories such as Maslow's self-actualization and Rogers's fully functioning person, and lifespan theories such as Jung's concept of individuation (Deci \& Ryan, 2008a). Ryff and Singer (2008) describe it as "dynamic, involving a continual process of developing one's potential ... and becoming, rather than achieving a fixed state wherein all problems are solved" (p. 21).

A popular definition of magic in Paganism is provided by (in)famous occultist Aleister Crowley as "the Science and Art of causing change to occur in conformity with Will" (e.g., Harvey, 1997; Reid, 1996; Seymour, 2005). Ruickbie (2011) explains that for Crowley "Will" does not simply refer to that which we desire; rather, it is the "True Will," which is more akin to the concept of "true self." Thus, magic becomes "the science of 'understanding oneself and one's conditions' and the art of 'applying this understanding in action" (Ruickbie, 2011, p. 195). This draws attention to the importance of the personal growth dimension in the practice of Paganism. In a survey of British Pagans, Ruickbie (2011) found that "personal development" was the second most popular reason for conducting magical rituals. When asked what effect practicing magic had, $60 \%$ stated 
that magic had had a profound effect on their lives, often this effect was one of personal transformation; "they had discovered themselves, improved themselves, solved their personal problems or expanded their awareness ... a large number specifically stated that magic had increased their self-confidence" (Ruickbie, 2011, p. 206).

To take part in Pagan practices is to actively choose a path of personal growth and self-empowerment. Noted Wiccan Priest and author, Stewart Farrar (1995) states that the basic aim of magic (regardless of the tradition/ system it is practiced in) is "the spiritual development of the individual ... and the expanding of his consciousness" (p. 118) to the extent that other effects of magic (i.e., successful spells for purpose) are merely by-products of this true purpose (p. 119). Farrar (1995) uses the Golden Dawn interpretation of the Sephiroth of the Kabbalistic Tree of Life as a framework for the stages of spiritual development attained in Pagan practice. The highest stage is "Ipsissimus," which Farrar explains "means literally 'one's very self' or 'most truly oneself' [and] expresses the goal of all Western magical Systems" (p. 120). This could be interpreted as referring to the self-actualized (Maslow) or fully functioning (Rogers) or Individuated (Jung) person. That so many theories from psychotherapy have influenced the construction of the personal growth dimension may explain the parallels between it and the concept of spiritual development in Paganism. Modern Paganism is strongly influenced by Jungian theory, and many Pagans understand the Goddesses, Gods, and other spiritual entities they work with as archetypal figures (Adler, 1986; Crowley, 1989; Starhawk, 1989), and spiritual growth occurs as a result of engaging with these figures in ritual. As Waldron and Waldron (2004, p. 37) explain, "through mythology and the embracing of the unconscious, as manifested through deeply resonant archetypal symbols, one can find wholeness and a sense of reconnection in a fundamentally alienated and disconnected world."

Magic and ritual practices are also seen as a metaphor for change (Rabinovich, 1996; Reid, 1996; Rountree, 2006; Waldron \& Waldron, 2004). Every Pagan ritual contains aspects of self-reflection and self-transformation, although this aim is more explicit in some rituals than in others (Berger, 1999). Rountree (2003) provides examples of two such spells conducted by covens, designed by and intended for specific members; the first was by a 20-year-old woman who wanted to cast off her feelings of inferiority and assert herself as an adult in her family, the second was by an older woman who wanted to "accept cronehood and ageing" (Rountree, 2003, p. 195). In both of these examples, the women used magical ritual practices to help them come to terms with the aging process, to accept their new roles, and to progress to the next stage of their life. 


\section{Self-Acceptance}

The above examples share the theme that rituals to aid personal growth often include elements that are focused on self-acceptance. Ryff (1989) defines self-acceptance as having a positive view of oneself, accepting both positive and negative aspects. Pagan practices can be particularly beneficial for women in helping them to cast off the marginalizing view of women imposed by a patriarchal society and instead to see themselves as valuable, worthy, and powerful. McPhillips (2003, pp. 76-77) discusses the importance of body-focused ritual practices for her all female Pagan group, stating that they provided

a major incentive to appreciate our bodies and what they could do, in very different ways to what we had been taught by the wider culture ... in participating in and creating these rituals, I experienced a deep sense of spiritual freedom and empowerment.

The matrifocal nature of Paganism provides women with a powerful, multifaceted role model (Morgan, 1995) and an inkling of their own divinity. This sense of divinity can be further reinforced through ritual practices such as "drawing down the Moon" where a female practitioner will invoke the Goddess into herself and may either recite the Charge of the Goddess (a ritual poem that is a promise of love and guidance from the Goddess) or other insights or revelations she may receive from the Goddess (Harvey, 1997; Orion, 1995). Through this ritual the female practitioner embodies the Goddess herself.

Pagan practice can be especially healing for those who identify as lesbian, gay, bisexual, transgender, queer/questioning, and others (LGBTQ+), particularly those who have come from other, less tolerant religions. Being part of a religion that condemns LGBTQ + individuals can have a serious negative impact on self-esteem (Beagan \& Hattie, 2015). Paganism, on the other hand, is not simply accepting of the LGBTQ + community; the sacralization of the body and of sex espoused in Paganism, and the embodiment inherent in Pagan rituals can provide LGBTQ + folks with a spirituality that celebrates their sexuality and allows them to see it as a source of joy, power, and worship rather than as something sinful to be denounced (Beagan \& Hattie, 2015).

Accepting both positive and negative aspects of the self is a key element of the transformative nature of Pagan ritual for all practitioners, and one that contributes to personal growth. Ezzy (2014) demonstrates this clearly when discussing two of the rites performed at "Faunalia," the 
pseudonym he gave to a Pagan festival: The Underworld rite examines death, deterioration, pain and vulnerability, while the Baphomet rite focuses on sexuality, sexual contravention, and alterity. Both explore concepts that are often considered taboo in Western culture but could be argued to be necessary to achieve a sense of wholeness and integrity. Through rituals such as these, and through the sanctity of the body and sex espoused in Paganism, participants are able to acknowledge, explore, and assimilate aspects of themselves that they may have previously rejected or repressed, leading to wholeness and greater self-acceptance. Coco and Woodward (2007) observed that a practitioner who failed to engage with the more serious aspects of Paganism such as moral responsibility and acknowledging the darker aspects of nature and human nature, was branded as a "Fluffy Bunny" or inauthentic Pagan, suggesting that this is a fundamental aspect of Pagan practice.

\section{Positive Relations With Others}

The next of Ryff's (1989) six dimensions to be considered is positive relations with others. Those who have positive relations with others have affectionate, empathic, intimate and trusting relationships and also understand the reciprocity involved in such relationships (Ryff \& Singer, 2008). In line with this, tolerance and equity are key values within Paganism (Berger, 1999; Magliocco, 2004). The coven provides a space within which these values are expressed, and relationships are formed. Pagan author Starhawk (1989) describes the role of the coven as "a Witches' support group, consciousness raising group, psychic study center, clergy-training program, college of Mysteries, surrogate clan, and religious congregation all rolled into one" (p. 35). Berger (1999) described her experiences with the Circle of Light coven in terms that reflect this function. Meetings began with a "check-in session" where members discussed their week, shared their feelings, and spoke of spiritual experiences. The aim was to enhance members' interpersonal skills (vital for any group process), and foster intimacy between group members especially as, over time, people began to share more personal information. Sessions were aided by a "facilitator" whose role was to "ensure that the group process does not result in a few people dominating the conversation and therefore the decision making process" (Berger, 1999, p. 57). Rituals ended with food, drink, and chat; eating after a magical working is believed to not only help "ground" an individual, bringing them back from a magical state of consciousness to a mundane one but also helped to foster intimacy between group members. Finally, as members departed, farewells usually involved hugging and kissing — another way 
to break down barriers and build relationships. The efficacy of these practices was clear, coven members referred to the coven as "family," this sentiment was mirrored in their interactions; when one coven member was taken ill and had to be hospitalized, the coven rallied around providing both magical support (in the form of healing spells), and practical support such as providing transportation to and from hospital, food shopping, and help with domestic chores (Berger, 1999). Like many Wiccan covens, the Circle of Light coven abides by the concept of "perfect love and perfect trust" "and aims to provide ... a place of safety and care" as well as a place of learning and practice (Berger, 1999, p. 52).

It would be disingenuous to claim that there is no discord in the Pagan community. As with any community, interpersonal disputes do occur, and they are often the reason why covens are dissolved, or individual members choose to move on. Covens can be fluid and short-lived, with members creating breakaway groups or dissolving the coven after a few months or years. This does not, however, weaken the importance of the relationships formed there. Many of these relationships endure even after members have left or the coven has disbanded, and even those that do not survive are still considered to have been important to those involved (Berger, 1999).

A large number of Pagans are described as solitary in the sense that they practice alone (Berger, 1999), but this does not mean that a sense of community, and the positive relationships that come with it, are absent for them. There are some organizations that Pagans can join to aid in networking such as the Pagan Federation and the UK Pagan Council, many online spaces exist that that allow Pagans to come together and share stories and discuss their religion. Coco (2012) uses the term Networked individualism to describe the combination of real life and online gatherings that has resulted in "ties to community [shifting] from linking people in particular geographic locale to linking people in any place thus enabling . . . opportunities to participate in 'communities of practice' that facilitate an overall sense of Pagan identity and belonging" (p. 1). York (1995) defines the Pagan community as a Segmented, Polycentric, Integrated Network (SPIN), which is explained by Gerlach (2001, pp. 289-290) in the following way:

Segmentary: Composed of many diverse groups, which grow and die, divide and fuse, proliferate and contract

Polycentric: Having multiple, often temporary, and sometimes competing leaders or centers of influence

Integrated Networked: Forming a loose, reticulate, integrated network with multiple linkages through overlapping membership, joint activities, common reading matter, and shared ideals and opponents 
The terms Networked individualism and SPIN both capture the diffuse yet connected nature of the Pagan community, that enables Pagans to retain autonomy (a key trait among Pagan practitioners, that will be discussed later in this article) while still reaping all the benefits of being part of a community.

One important instantiation of this network is found in festivals. Advertisements for Pagan festivals often emphasize their community-building nature (Pike, 2001). Ezzy (2014) explains that festivals often evoke a feeling of "Communitas," which he defines as "a deeper sense of community in which relationships are more intimate and open" (p. 55). This feeling is more intense than the camaraderie that might be experienced in mundane life, and are felt even more acutely in ritual states of consciousness. Ezzy (2014) limits feelings of communitas to festivals, but it could be argued that these feelings are evoked in almost all Pagan rituals-Psychologist and Pagan author Vivianne Crowley (1989) claims that "entering a circle is one of the most intimate things one can do with another" (p. 68). Even solitary rituals can elicit a sense of belongingness as, for some Pagans, one aim of ritual is to reassert a sense of connectedness to all things. As one practitioner in Sonnex's (2017, p. 184) study states,

[magic helps us to] remain connected ... to deity, to everything, however we perceive it, and remaining connected to the earth and the wind and the sky and the sea and it all sounds very ephemeral but those things are all in us too.

The concept of interconnectedness is a central part of the Pagan world view (Pike, 2001; Sonnex, 2017), espousing that all beings are connected in an intricate web, and through this web of connections magic is able to effect change (Magliocco, 2004; Sonnex, 2017). Tapping into this web of interconnectedness during ritual provides practitioners with a renewed feeling of connection (Adler, 1986). So, while Pagan communities may look different to more traditional faith communities, it is clear to see that not only do these communities exists but also that the positive relationships within them are strengthened through ritual practices.

\section{Autonomy}

One of the reasons Pagan religious communities look different from more traditional religious communities is the balance between connection and autonomy that defines them. Autonomy is one of the dimensions of personal well-being identified by Ryff (1989). When defining autonomy, Ryff and Singer (2008) draw on a number of different theories and concepts, including 
Maslow's characterization of self-actualizers as resistant to enculturation, described by Rogers's description of the fully functioning person as having an internal locus of evaluation, and Jung's description of freedom from tradition as part of Individuation.

Autonomy is another central element of Paganism. Sonnex (2017) found that being able to dictate how one practices one's faith, rather than having to adhere to circumscribed practices is a defining aspect of Paganism for many; having spiritual intermediaries such as clergy was felt to dilute personal experience of the divine. She demonstrates this using a quote from one of her participants, Athena:

I think the personal spiritual authority . . . is huge . . not all faith traditions have personal spiritual authority.... So your experience with the divine is then mediated through that second or third party and I really, I'm all about the experiential ... so I was looking for an unmediated experience ... the fact that I have my own personal spiritual authority and I can have the unmediated experience with the divine are ... the two most crucial things for me. (p. 130)

Sonnex (2017) called this autonomy "spiritual agency" and likened it to Bandura's (2001) theory of human agency, which identified three modes: personal, proxy, and collective, with the first two being the most relevant. Personal agency is the capacity for individual choice and action. Proxy agency, on the other hand, occurs when we relinquish our agency to others who are more knowledgeable, experienced, or influential, to act on our behalf. Clergy or gurus can be understood to act as proxy agent in the religiospiritual sphere given their training, experience, and positions of authority in religious organizations. Bandura (2001) explains that proxy agents are often utilized because effectively exercising personal agency requires one to become adroit in the field in which one might otherwise seek a proxy agent. Exercising personal agency necessitates assuming responsibility and accountability, which deters many people. For Pagans, this proxy agency is rejected in favor of personal spiritual agency. With spiritual agency comes responsibility for one's own spiritual education that in other religions would have been assumed by a priest or clergy figure; in contrast, for many Pagans initial forays into Paganism were self-directed. This autonomy also extends to the moral and ethical milieu; Pagans have a self-directed morality which states that they alone are responsible for their actions and their effects. Sonnex (2017) demonstrates this point with a quote from another participant, Donkey:

I think [the most important thing about being Pagan [is] probably responsibility for one's own life without turning to some ... all-powerful, deity to sort of say, "ok so what do I do now?" and sort of, and/or "I'm sorry Sir, is that ok now?" 
. . . twenty Hail Marys and off we go. . . . so I think it's, that's extremely important, taking responsibility, I mean your own conscience doesn't lie to you. (p. 151)

Practitioners must face the consequences of their actions and, as a result of this personal accountability, Pagan ethical responsibility might reasonably be argued to be more autonomous than religions that offer absolution.

Both Bloch (1998) and Ezzy (2003) believe that the emphasis on autonomy within Paganism is indicative of it being a modern religion and a product of the modern Western zeitgeist of individualism, reflexivity, and focus on the self. This mirrors Ryff and Singer's (2008) assertion that autonomy is "undoubtedly the most western of all the ... dimensions" (p. 23). Bloch (1998) investigated specifically the autonomy within alternative spiritualities, which he defined as "world religions, pop psychology, New Age "parapsychology', Neo-Pagan spell casting and the occult" (p. 56). According to Bloch, these spiritualties were considered alternative precisely because of their rejection of dogma and their emphasis on "individual self-autonomy" (p. 61). Bloch's interviewees explained that although books can provide information, it is direct experience that provided the basis for their belief and practices, so that they often rejected spiritual or religious authority. This prioritizing of autonomy is something that has been identified by other researchers of the Pagan community. Orion (1995) in her study of American Neo-Pagans found that her participants shunned figures of religious or spiritual authority (p. 42) and concluded that the desire for autonomy was "one of the greatest inducements to study magic" (p. 162). Adler (1986) likewise found that one of the six main reasons why people feel compelled to practice Paganism was "freedom," which she describes as the ability to act as one chooses without having to comply with other people's notions of what is right or wrong. In the opening paragraph to her book Drawing down the moon: Witches, Druids, Goddess-Worshippers and other Pagans in America Today, Adler describes Pagans as "Eclectic, individualist and often fiercely autonomous" (p. 3), establishing immediately how definitive the characteristic is. When describing the common characteristics of the participants in her work, Luhrmann (1989) stated that Pagans are often rebellious and concerned with issues of control. Rebellion is often understood to be a rejection of the authority of others and Pagans cherish the control of their personal practices that Paganism affords them.

Orion (1995) proposes that the combination of autonomy and an appreciation of traditional or folk magic practices makes the image of the historical witch very appealing to modern Pagans. Many understand that accusations of witchcraft were a reaction to perceived assertions of independence - autonomy 
was viewed as a challenge to the power structures of the time. Orion concludes, "This is the power contained within the witch archetype that contemporary witches are attempting to release and harness. It is, in essence, self-sufficiency" (p. 114).

\section{Environmental Mastery}

While autonomy is about "self- determination, independence, and regulation of behaviour from within" (Deci \& Ryan, 2008a, p. 1), environmental mastery, the next dimension to be considered, is concerned with control of the outside world. Ryff and Singer (2008) describe those high in environmental mastery as demonstrating "a sense of mastery and competence in managing the environment; controls complex array of external activities; makes effective use of surrounding opportunities: able to choose or create contexts suitable to personal needs and values" (p. 25). Environmental mastery is strongly linked to autonomy, which in Paganism is expressed through shaping one's spiritual environment as one sees fit, rather than following prescribed practices. This is especially evident when it comes to the design of ritual practices. Sonnex (2017) found that practitioners emphasized the importance of working in a way that feels right for them. This freedom allows Pagan practitioners to create a personally meaningful and effective set of practices that evoke a sense of liminality that is conducive to flow.

Rituals that serve some external purpose (i.e., spells) are an obvious way in which Pagan practices foster a sense of environmental mastery. Spells for purpose are intended to effect change, most commonly in the form of healing spells (Ruickbie, 2011; Willin, 2007) but also as spells for personal, social, or situational advantage (Ruickbie, 2011), for example to find a job or a new house. How Pagans understand the mechanisms behind spells, whether as the result of a psychological change in the practitioner's consciousness, or as the result of actual changes in the environment manifested as a result of manipulation of energies, varies between practitioners (Adler, 1986; Harvey, 1997; Ruickbie, 2011). However it is that spells are believed to work, they are considered to be effective and to allow the practitioners a level of control over their own lives or the lives of those for whom they perform the working.

\section{Purpose in Life}

The final dimension to be discussed is purpose in life. Ryff and Singer (2008) define purpose in life as comprising beliefs that there is purpose and meaning to life, which in turn give rise to goal setting and a sense of directedness. This mirrors Steger's (2013) description of meaning in life as being made up of 
cognitive and motivational aspects. For Steger (2013), the cognitive aspects are comprised of people's comprehension of the world around them whereas the motivational aspects are related to one's investment in a self-concordant purpose. It is the former aspect of purpose that Pagan practice contributes to most clearly and that will be discussed here. Steger argues that "the goals people develop are most beneficial when they arise naturally from the unique ways they comprehend life; when the cognitive component of meaning provides the springboard for the motivational component" (p. 166), suggesting that the broader, cognitive aspect of meaning in life can also influence the narrower, motivational aspect.

There is a wealth of evidence demonstrating a link between religiosity/ spirituality and positive mental health outcomes (e.g., Joshanloo, 2011; Koenig, 2009). More recently, research suggests that this link can be explained in terms of the capacity of religiosity/spirituality to imbue life with meaning. Ivtzan et al. (2013) found spirituality, either individually or in conjunction with religiosity, positively correlated with participants' sense of meaning in life. Steger and Frazier (2005) found that over 90\% of the relationship between religiosity/spirituality and well-being could be accounted for by treating meaning in life as a mediator, and Khumalo et al. (2014) found similar results with a South African sample. Although this research did not include Pagan participants, it is likely that Paganism confers the same benefits on practitioners.

A key part of the Pagan cosmology is "the Wheel of the year"; a metaphor for the cycle of death and rebirth seen in the changing of the seasons (Berger, 1999; Magliocco, 2004; Starhawk, 1989). The wheel of the year is made of up of eight "Sabbats," or holy days, four of which fall on the solstices and equinoxes and four of which fall on fixed days in between (see Figure 2). The celebration of these sabbats can imbue practitioners with the feeling that there is structure and purpose to life. There are a number of metaphors applied to the wheel of the year, such as the story of Demeter and Persephone, or the story of the Oak King and Holly King. The most common myth depicts the Earth as a Goddess and plant life as the God whose role is that of son and consort. He is born at Yule, is joined with the Goddess at Beltane, reaches his peak at the summer solstice, and dies at Samhain to be reborn again (Magliocco, 2004).

These metaphors apply not only to the changing of the seasons but also to human experiences, as Starhawk (1989, p. 44) explains, "waxing and waning, birth and death, take place in the human psyche and life cycle. Each is to be welcomed in its proper time and season, because life is a process of constant change." This parallel of cycles in nature with cycles in human life is seen in the mythology of the Goddess in particular. In many traditions the 


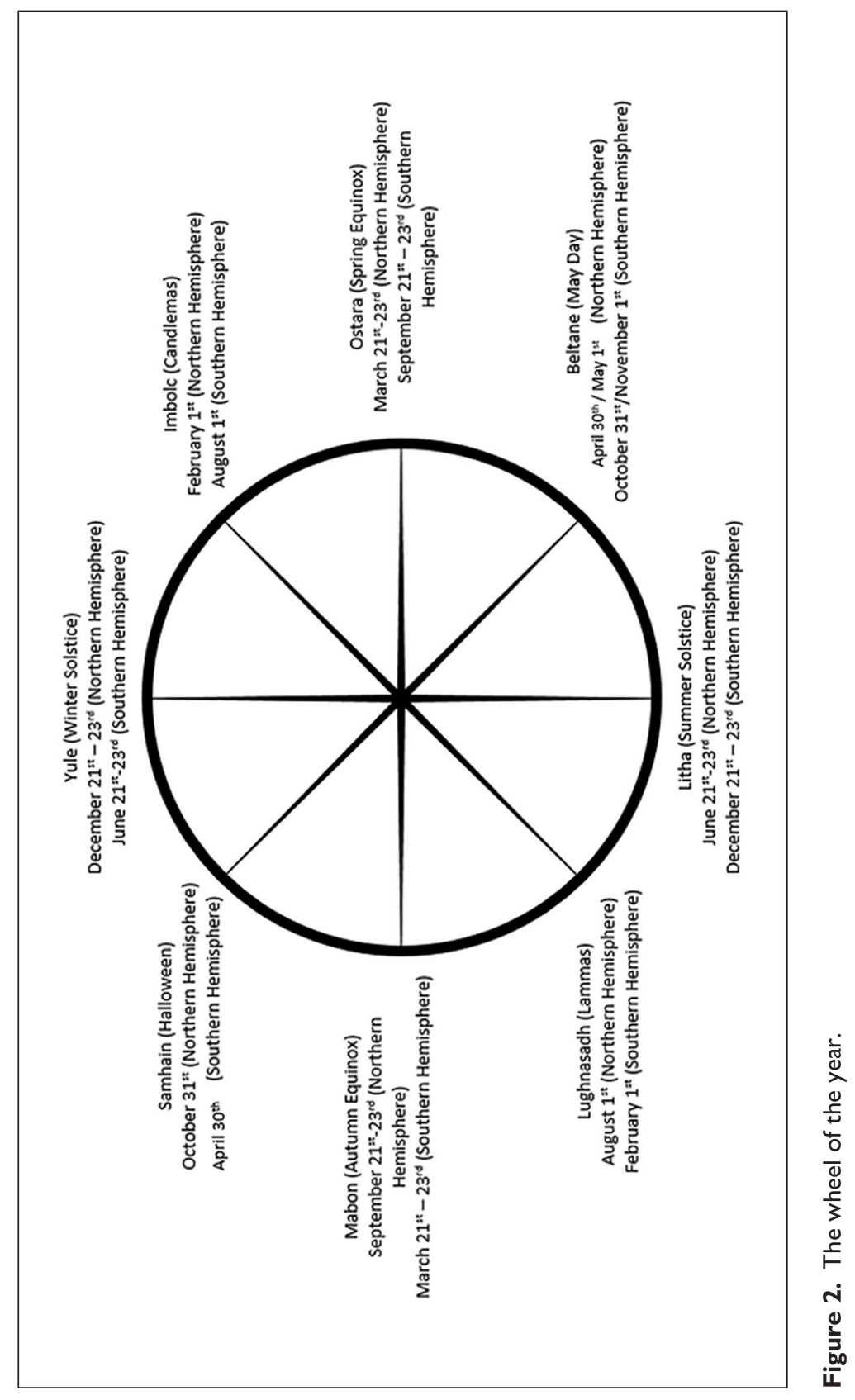


Goddess is seen as a trinity of maiden, mother, and crone. She is seen as an avatar of the moon and so these three aspects reflect the moon phases of waxing, full, and waning, they also reflect the three stages of womanhood; youth (pre-menarche), adulthood, and older adulthood (post-menopause), with some women taking part in rites of passage, at menarche and/or menopause, to mark their transition from one phase to the next (McPhillips, 2003). By celebrating the changing of the seasons as represented by the turning of the wheel of the year, and moon cycles as the three aspects of the Goddess, practitioners are reinforcing the cyclical nature of time, imbuing the world and their experiences in it, with a sense of order and meaning (Berger, 1999; Harvey, 1997; Magliocco, 2004).

As with other religious/spiritual beliefs, Paganism can foster a sense of purpose in life that makes distressing life events meaningful and therefore tolerable. Hood et al. (2018) explain that finding meaning "probably constitutes the core of successful coping and adjustment" (p. 485), religion provides this meaning particularly in distressing situations, and helps not only in dealing with the negative emotions that arise but also with problem solving. Reid (1996) describes how Pagan magical practices can be particularly beneficial to those who have survived trauma and abuse, comparing the techniques of magical training with those prevalent in self-help literature. She explains that because magical practice involves developing a depth of knowledge about one's self (as discussed in the "Self-Acceptance" subsection of this article), experiences and feelings are naturally acknowledged, reexamined and reevaluated, especially those considered "dark." It is understood in Paganism that power is gained through successfully overcoming the challenge of facing our inner demons (Luhrmann, 1989; Reid, 1996); doing so tests our resilience and strength of will.

\section{Conclusion}

In this article, we have considered Pagan practices from the perspective of Flow, Liminality, and Eudaimonia to explore the ways in which being a Pagan might confer well-being benefits. We have argued that the Liminal, flow experiences inherent in Pagan practice provide a pathway to eudaimonia by fostering all six of Ryff's (1989) dimensions of psychological well-being.

Personal development was shown to be a key reason for conducting rituals, especially those designed to help the practitioner come to terms with major life changes. Engaging with archetypal figures in ritual allows practitioners to explore aspects of themselves that may otherwise have been neglected, and thus, contributes to the process of personal growth. Through the veneration of the feminine divine, the sacralization of the body and of sex, and the embracing of the darker aspects of human nature, Pagan practices 
provide a counterpoint to negative and limiting norms, values, attitudes, and beliefs. This promotes a sense of self-acceptance in practitioners, especially those from marginalized groups. Pagan communities strike a balance between independence and fellowship, with covens providing a congregational type of experience that comprises part of a wider, more diffuse network that encourages positive relations with others. The liminal, flow experiences of Pagan ritual foster a sense of communitas among those participating. These rituals also allow participants to reaffirm their place in a web of interconnectedness, such that even solitary practitioners benefit from an increased sense of relatedness as a result.

Autonomy is a key element of Paganism. It is instantiated in the lack of clergy and the self-directed nature of morality, and is often a motivating factor in the decision to adopt these practices. This emphasis on self-determination means that Pagans can exercise mastery of their spiritual environment, dictating what their rituals look like and how they should be performed. Many Pagans further achieving feelings of environmental mastery to working magic to effect change in their lives.

The tenets of magic provide practitioners with a way to reframe traumatic experiences as empowering tests of will, thereby assigning meaning to such experiences and making them easier to cope with. The Pagan cosmology is centered around natural cycles, with rituals designed to mark key points in the seasonal calendar and in their own lives that affirm belief in an ordered universe and imbues practitioners' lives with meaning.

Given the close parallels we have identified, we would argue that modern Pagan beliefs and practices provide a valuable insight into processes that engender flow and facilitate personal and interpersonal growth. In our view, further detailed research with this relatively neglected religious community is likely to prove most fruitful.

\section{Declaration of Conflicting Interests}

The author(s) declared no potential conflicts of interest with respect to the research, authorship, and/or publication of this article.

\section{Funding}

The author(s) received no financial support for the authorship, and/or publication of this article. We should like to acknowledge the kind support of a Bial Foundation grant $(128 / 10)$ that enabled us to conduct the empirical research described in this paper.

\section{ORCID iDs}

Chris A. Roe (iD https://orcid.org/0000-0001-8294-4758

Elizabeth C. Roxburgh (iD https://orcid.org/0000-0002-8086-9501 


\section{Note}

1. Pagan practice involves rituals that utilize magic; those done to mark the seasons are referred to as rituals, those done to bring about a specific aim, tend to be referred to as "spells." However, the distinction between a spell and a ritual can sometimes be blurred since they tend to follow the same pattern, so that the term working is often used to refer to them collectively. To reflect this, the terms ritual, working, magic, and spells will be employed interchangeably in this article.

\section{References}

Adler, M. (1986). Drawing down the moon: Witches, druids, goddess-worshippers and other pagans in America today (Rev. and expanded ed.). Beacon Press.

Beagan, B. L., \& Hattie, B. (2015). Religion, spirituality, and LGBTQ identity integration. Journal of LGBT Issues in Counseling, 9(2), 92-117. https://doi.org/10.1 080/15538605.2015.1029204

Berger, H. A. (1999). A community of witches: Contemporary neo-paganism and witchcraft in the United States. University of South Carolina Press.

Butler, J. (2004). Neo-pagan ritual practice as visual culture and creative expression of identity. In M. Nic Craith \& U. Kockel (Eds.), Communicating cultures: European studies in culture and policy (pp. 108-128). Lit Verlag.

Clifton, C. S., \& Harvey, G. (Eds.). (2004). The paganism reader. Routledge.

Coco, A. (2012). Pagan religiousness as 'networked individualism'. In M. Fowler, J. D. Martin \& J. L. Hochheimer (Eds), Spirituality: Theory, praxis and pedagogy (pp. 125-136). Inter-Disciplinary Press. ISBN: 9781848880917

Coco, A., \& Woodward, I. (2007). Discourses of authenticity in a pagan community: The emergence of the 'fluffy bunny' sanction. Journal of Contemporary Ethnography, 36(5), 479-504.

Crowley, V. (1989). Wicca: The old religion in the new age. Scranton, PA: Thorsons Pub.

Csikszentmihalyi, M. (1975). Beyond boredom and anxiety. Jossey-Bass.

Cunningham, S. (2003). Wicca: A guide for the solitary practitioner. Llewellyn.

Deci, E. L., \& Ryan, R. M. (2008a). Hedonia, eudaimonia, and well-being, an introduction. Journal of Happiness Studies, 9(1), 1-11. https://doi.org/10.1007/ s10902-006-9018-1

Deci, E. L., \& Ryan, R. M. (2008b). Self-determination theory: A macrotheory of human motivation, development, and health. Canadian Psychology/Psychologie Canadienne, 49(3), 182-185. https://doi.org/10.1037/a0012801

Dierendonck, D. V., \& Mohan, K. (2006). Some thoughts on spirituality and eudaimonic well-being. Mental Health, Religion and Culture, 9(3), 227-238. https:// doi.org/10.1080/13694670600615383

Ezzy, D. (2014). Sex, death and witchcraft: A contemporary pagan festival. Bloomsbury.

Farrar, J., \& Farrar, S. (1992). Spells and how they work. London: Robert Hale Ltd. 
Farrar, S. (1995). What witches do. Robert Hale.

Gerlach, L. P. (2001). The structure of social movements: Environmental activism and its opponents. In J. Arquilla \& D. Rondfeldt (Eds.), Networks and netwars: The future of terror, crime, and militancy (pp. 289-310). RAND.

Green, M. (1991). A witch alone: Thirteen moons to master natural magic. London: Thorsons.

Harvey, G. (1997). Listening people, speaking earth: Contemporary paganism. London: Hurst \& Co.

Hood, R.W., Hill, P. C., \& Spilka, B. (2018). The psychology of religion: An empirical approach (5th ed.). London: Guilford Press.

Hume, L. (1998). Creating sacred space: Outer expressions of inner worlds in modern Wicca. Journal of Contemporary Religion, 13(3), 309-319. https://doi. org/10.1080/13537909808580838

Ivtzan, I., Chan, C. P., Gardner, H. E., \& Prashar, K. (2013). Linking religion and spirituality with psychological well-being: Examining self-actualisation, meaning in life, and personal growth initiative. Journal of Religion and Health, 52(3), 915-929. https://doi.org/10.1007/s10943-011-9540-2

Jones, P. (1996). Pagan theologies. In G. Harvey \& C. Hardman (Eds.), Paganism today: Wiccans, Druids, the Goddess, and Ancient Earth traditions for the twenty-first century (pp. 32-46). Thorsons.

Jones, P. (1998). The European native tradition. In J. Pearson, R. H. Roberts, \& G. Samuel (Eds.), Nature religion today: Paganism in the modern world (pp. 7788). Edinburgh University Press.

Joshanloo, M. (2011). Investigation of the contribution of spirituality and religiousness to Hedonic and Eudaimonic well-being in Iranianyoung adults. Journal of Happiness Studies, 12(6), 915-930. DOI: 10.1007/s10902-010-9236-4

Khumalo, I. P., Wissing, M. P., \& Schutte, L. (2014). Presence of meaning and search for meaning as mediators between spirituality and psychological well-being in a South African sample. Journal of Psychology in Africa, 24(1), 61-72. https://doi. org/10.1080/14330237.2014.904095

Koenig, H. G. (2009). Research on religion, spirituality, and mental health: A review. The Canadian Journal of Psychiatry, 54, 283-291.

Luhrmann, T. (1989). Persuasions of the witch's craft: Ritual magic in modern culture. Harvard University Press.

Magliocco, S. (1996). Ritual is my chosen art form: The creation of ritual as folk art among contemporary pagans. In J. R. Lewis (Ed.), Magical religion and modern witchcraft (pp. 93-120). State University of New York Press.

Magliocco, S. (2004). Witching culture: Folklore and Paganism in America. University of Pennsylvania Press. https://doi.org/10.9783/9780812202700

McPhillips, K. (2003). Feminist spirituality and the power of ritual. In D. Ezzy (ed). Practising the witch's craft. Sydney: Allen and Unwin.

Morgan, L. (1995). Women and the Goddess today. In G. Harvey \& S. Hardman (Eds) Paganism Today (pp. 94-108). Thorsons.

Office for National Statistics. (2001). Census 2001. https://www.ons.gov.uk/ census/2001 censusandearlier 
Office for National Statistics. (2012). 2011 Census. https://www.ons.gov.uk/ census/2011census

Orion, L. (1995). Never again the burning times: Paganism revived. Waveland Press.

Pargament, K. I., Wong, S., \& Exline, J. J. (2016). Wholeness and holiness: The spiritual dimension of eudaimonics. In J. Vittersø (Ed.), Handbook of eudaimonic well-being (pp. 379-394). Springer.

Pike, S. M. (2001). Earthly bodies, magical selves: Contemporary pagans and the search for community. University of California Press.

Rabinovitch, S. T. (1996). Spells of transformation: Categorizing modern Neo-Pagan witches. In J. R. Lewis (Ed), Magical religion and modern witchcraft (75-92). State University of New York Press.

Reber, A. (1985). The penguin dictionary of psychology. Penguin.

Reid, S. (1996). As I do will, so mote it be: Magic as metaphor in Neo-Pagan witchcraft. In J. R. Lewis (Ed.), Magical religion and modern witchcraft (pp. 141-167). State University of New York Press.

Rountree, K. (2003). Embracing the witch and the goddess: Feminist ritual-makers in New Zealand. London: Routledge

Rountree, K. (2006). Performing the divine: Neo-pagan pilgrimages and embodiment at sacred sites. Body and Society, 12(4), 95-115. https://doi. org/10.1177/1357034X06070886

Ruickbie, L. (2011). Witchcraft out of the shadows: A complete history. Robert Hale.

Ryan, R. M., \& Deci, E. L. (2001). On happiness and human potentials: A review of research on hedonic and eudaimonic well-being. Annual Review of Psychology, 52(1), 141-166. https://doi.org/10.1146/annurev.psych.52.1.141

Ryan, R. M., Huta, V., \& Deci, E. L. (2008). Living well: A self-determination theory perspective on eudaimonia. Journal of Happiness Studies, 9(1), 139-170. https:// doi.org/10.1007/s10902-006-9023-4

Ryff, C. D. (1989). Happiness is everything, or is it? Explorations on the meaning of psychological well-being. Journal of Personality and Social Psychology, 57(6), 1069-1081. https://doi.org/10.1037/0022-3514.57.6.1069

Ryff, C. D., \& Singer, B. H. (2008). Know thyself and become what you are: A eudaimonic approach to psychological well-being. Journal of Happiness Studies, 9(1), 13-39. https://doi.org/10.1007/s10902-006-9019-0

Seymour, E. (2005). Pagan approaches to healing. In R. Moodley \& W. West (Eds.), Multicultural aspects of counseling series (Vol. 22, p. 233). Sage. https://doi. org/10.4135/9781452231648.n20

Shadrack, J., Sonnex, C., \& Roe, C. A. (2019). Ritual occultation and the space between worlds: Exploring the discursive nature of the "flow" state in Black metal and Pagan performative practice. In C. McLaughlin (Ed.), Trans-states: The art of crossing over (pp. 64-86). Fulgur Press.

Sonnex, C. (2017). Extending the non-contact healing paradigm to explore distant mental interaction effects of pagan healing spells [Doctoral thesis]. 
University of Northampton. http://nectar.northampton.ac.uk/9733/1/Sonnex Charmaine_2017_Extending_the_Non_Contact_Healing_Paradigm_to_ Explore_Distant_Mental_Interaction_Effects_of_Pagan_Healing_Spells.pdf Starhawk. (1989). The spiral $\bar{d}$ ance: A rebirth of the ancient religion of the great goddess (2nd ed.). HarperSanFrancisco.

Steger, M. F. (2013). Experiencing meaning in life: Optimal functioning at the nexus of well-being, psychopathology, and spirituality. In P. T. P. Wong (Ed.), The human quest for meaning (pp. 165-184). Routledge.

Steger, M. F., \& Frazier, P. (2005). Meaning in life: One link in the chain from religiousness to well-being. Journal of Counseling Psychology, 52(4), 574-582. https://doi.org/10.1037/0022-0167.52.4.574

Turner, V. (1983). Liminal to liminoid, in play, flow and ritual: An essay in comparative symbology. In J. C. Harris, \& R. J. Park (Eds.), Play, games and sports in cultural contexts (pp. 123-164). Champaign, ILL: Human Kinetics Publishers Inc.

Waldron, D., \& Waldron, S. (2004). Jung and the neo-pagan movement. Quadrant: The Journal of the C.G. Jung Foundation for Analytical Psychology, XXXIV(1), 29-46.

Waterman, A. S. (1990). Personal expressiveness: Philosophical and psychological foundations. Journal of Mind and Behavior, 11(1), 47-73. https://www.jstor.org/ stable/43853486

Waterman, A. S. (1993). Two conceptions of happiness: Contrasts of personal expressiveness (eudaimonia) and hedonic enjoyment. Journal of Personality and Social Psychology, 64(4), 678-691. https://doi.org/10.1037/0022-3514.64.4.678

Willin, M. (2007). Paranormal phenomena in British witchcraft and Wiccan culture with special reference to spellcraft. Journal of the Society for Psychical Research, 71(2), 65-79.

York, M. (1995). The emerging network: A sociology of the New age and Neo Pagan movements. Rowman \& Littlefield.

\section{Author Biographies}

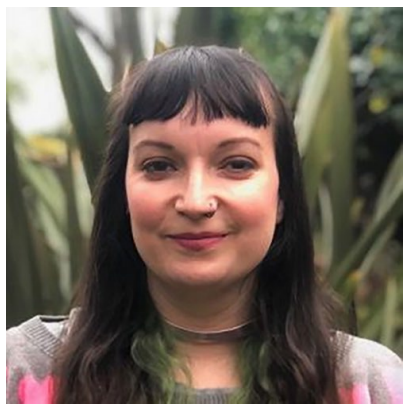

Charmaine Sonnex is a lecturer in psychology at the University of Buckingham and a committee member for the British Psychological Society Transpersonal section. She studied at the University of Northampton for her BSc (Hons) in Psychology, and MSc in Transpersonal Psychology and Consciousness studies. She also completed her $\mathrm{PhD}$ exploring neo-pagan healing spells at the University of Northampton. Her research interests are in the fields of Transpersonal Psychology, the Psychology of religion and spirituality, and neopaganism. She uses both qualitative and quantitative research methods. 


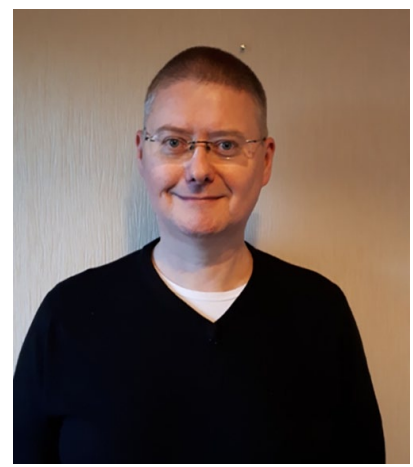

Chris A. Roe is a professor of psychology at the University of Northampton, UK, and director of the Centre for the Psychology and Social Sciences that is based there. He is the PerrottWarrick Senior Researcher (Trinity College, Cambridge) and Visiting Professor at Bucks New University. He is the president of the Society for Psychical Research and the International Affiliate for England of the Parapsychology Foundation. He has served as the chair of the British Psychological Society Transpersonal Psychology Section, and as the president of the Parapsychological Association. $\mathrm{He}$ is an associate editor for the Journal of Parapsychology and is on the editorial board for the Journal of the Society for Psychical Research and the Transpersonal Psychology Review. His research interests are around understanding the nature of anomalous experiences and includes research on the phenomenology of paranormal experience, particularly as it affects well-being, the psychology of paranormal belief and of deception, as well as experimental approaches to test claims for extrasensory perception and psychokinesis, particularly, where they involve psychological factors. Recent research has been concerned with the relationship between altered states of consciousness and psychic experience. He has published over 100 journal articles and book chapters and given over 200 conference presentations.

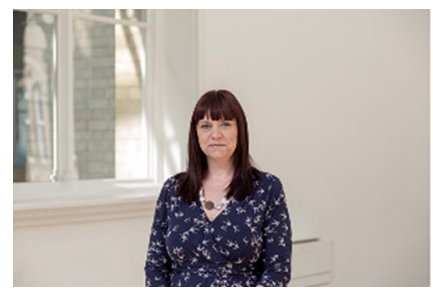

Elizabeth C. Roxburgh is a senior lecturer in Psychology at Canterbury Christ Church University. She is a fellow of the Higher Education Academy and her subject expertise is counselling, mental health, psychology of anomalous experiences, and qualitative research methods. She supervises both undergraduate and postgraduate research projects. Her research interests fall under the broad remit of well-being with a focus on critical approaches, phenomenology of anomalous experiences and beliefs, counselling training and client perspectives, spirituality, and nature. She is currently researching Sensory Processing Sensitivity. She previously worked for Nottingham Trent University and the University of Northampton and was course leader for a BSc (Hons) Psychology and Counselling degree. She is a qualified counsellor and has worked for the National Health Service and the voluntary sector in a variety of mental health and forensic contexts. 